\author{
Anna BARWIŃSKA-MAŁAJOWICZ1 \\ Kamila TECZA ${ }^{2}$
}

\title{
EDUCATIONAL CAPITAL AS A TYPE OF CAREER CAPITAL OF HIGHER EDUCATION GRADUATES
}

\begin{abstract}
Taking into consideration the dynamics of changes in the modern labor market, the issue of building career capitals by university graduates, becomes the subject of research, the exploration of which results in a thorough diagnosis of the mismatch problem or inadequate use of the potential of future employees. The career capital structure can distinguish its various types such as educational capital. Despite the fact that educational capital as a single factor, is not enough for achieving the professional success (or even to gain and maintain employment), on the stage of a knowledge-based economy, education is an essential condition for increasing human capital, both in the national, organizational and individual aspect.

The main aim of this article is to present the essence and types of career capital with special consideration for educational career capital and also to outline selected determinants of building educational career capital by higher education graduates. The analysis was based on data on students and graduates of higher schools in Poland from the academic year 2017/2018. The methods used in this article are: critical analysis of the content of documents with statistical data as well as analysis and verification of the national and foreign literature on the subject.
\end{abstract}

Keywords: career capital, education, university graduates.

\section{INTRODUCTION}

Constant changes on labor market and in the area of education, generate new challenges in creating a professional career. The role and value of so-called career capital (employee's knowledge and professional skills, as well as abilities, motivation, health, attitudes and values) are becoming more and more important. In this regard, paying more research attention to the process of gathering career capital, including educational capital is reasonable. Despite the fact that educational capital as a single factor is not enough for gaining the professional success (or even to gain and maintain employment), on the stage of a knowledge-based economy, education is an essential condition for increasing human capital, both in the national, organizational and individual dimensions.

The main aim of this study is to present the essence and types of career capital with special consideration for educational career capital and also to outline selected determinants

1 Anna Barwińska-Małajowicz, DSc PhD, Associate Prof., University of Rzeszow, Tadeusza Rejtana 16C, 35-310 Rzeszow, e-mail: abarmal@gmail.com (corresponding author). ORCID: 0000-0002$-0228-1761$.

${ }^{2}$ Kamila Tęcza, MSc, University of Rzeszow, Tadeusza Rejtana 16C, 35-310 Rzeszow, e-mail: tecza.kamila@wp.pl. ORCID: 0000-0002-1602-0204. 
of building educational career capital by higher education graduates. In order to outline the relevance of selected issues related to the chosen subject and to indicate the context and theoretical background for the addressed issues, the authors used some methods such as: a critical analysis, verification of the literature (national and international) and analysis of the content of documents containing statistical data (including CSO and Work Service reports). After the synthetic explanation of the conceptual categories of capital and careers, the authors present the essence and types of career capital. Further part of the article focuses on the selected determinants of building educational capital by young people. Whole article ends up with a synthetic summary of the taken considerations.

\section{CAPITAL AND THE CAREER AS A PART OF CAREER CAPITAL}

Among traditional factors of production: work and land, capital is also the factor that stands out. It is one of the basic economic categories of modern economy, a category that has been present in all economic theories for a long time, ambiguous and differently interpreted, around which there is a polemic about its conceptualization. Economic sciences do not have any definition that might be unequivocal and accepted by everyone. So far, capital as a term has various definitions, dimensions and classifications. Luca Pacioli, who can be considered as a creator of definition of capital, in his extensive study from the year 1494 explains the principles of double accounting. Pacioli, in reference to a person who starts a trade business, formulates some definitions, among which a capital category appears (Pacioli, 2007). The definitions presented by L. Pacioli are rather lapidary so we are not able to decode it in the meaning of the concept of capital used by this author. However, it can be said that "the early use of the term - capital, or rather capitall, referred more to a holistic conceptualization of whole merchant's assets or only the net portion (excluding debts)" (Dobija, Dobija, 2003). In the opinion of J.W. Gościński, "capital is the least studied factor, which change its composition, degree of liquidity, source (origin) etc." (Gościński, 1989). Source literature analysis shows that the original meaning of the term capital was related to the amount of borrowed money or the debt (in contrast to the interest) (lac. capitalis pars debiti). It also meant the amount of money, necessary to set up a trade business (Marchewka, 2000). In one of the glossary from 1678 we can find another definition referring to capital - capitale dicitur bonum omne quod possidetur - according to which the term "capital" means all possessed goods (Taghizadegan, http). Originally, capital was equal to the gathered income, things and objects which were the products of human labor, assets and all resources of productive forces (Grodzicki, 2003). I. Fisher defined capital in similar way "capital covers all existing wealth and the value of goods that create it" (Marchewka, 2000). In economic theories there are many definitions about capital, based on different dimensions, in macro and micro scale. It is an economical category, which has certain value with growth ability. On the other hand, capital term also includes some amount of goods (especially those with technical and manufacturing capabilities) made by human.

Study shows, that the term capital expanded, split and was specified over time. As a result of enriching it with a suitable adjective (which describe the type of capital), brand new terms came out e.g. reserves capital, depreciation capital, social capital, network capital, intelectual, structural, relational, political, human capital etc. The considerations carried out in this study are focused on the last of the mentioned capitals - human capital. Moreover, it will be extended with a concept that is its direct derivative, i.e. career capital. 
The career capital analysis requires a brief outline of the second conceptual category: career (in the context of undertaken studies the authors will especially describe the type that refers to professional career).

The concept of career was constantly modified over time. It comes down from a Latin word carrus (cart) and also from Italian carriera - road, race track, chase, run. In ancient history, career was connected to success and broadly understood activities in the political sphere. Using this word more frequently led to a large expansion of the importance of this conceptual category (Cybal- Michalska, 2013).

Career is the polysemic term that more often is combined with success on the professional ground (Penc, 1997). It should be mentioned that different authors defines career with various categories. Some of them describes career as an attribute that is specific for human being (jobs, promotions, professional experience and activities collected during life) (Barwińska-Małajowicz, 2013). Others depicts career as a structural attribute of profession or organization (Banka, 2004). In the first concept, career should be more widely described as e.g. progress, achieving further levels of professional development and related profits (not only those related to the financial sphere) (Krause, 2006).

The most often cited explanation of professional career belongs to D. Super and it is said that

career is a group of events that has happened during the human life; a sequence of subsequent professional work and other life roles, that after connection express the level of the individual's involvement in the work in his general pattern of self-development; a series of jobs (from youthful period to the retirement period) where human receives payment or not, in which profession is only one of many factors related to this job. Another important factors are e.g. the role of student, worker, retirees or on the other hand non-work roles: the role in the family or society. We can talk about proper career only when someone is self-developing (Super, 1976).

According to the point of view mentioned above, career is a sequence of positions occupied by a representative that is typical for chosen profession or may be perceived as a path of mobility within a given organization (Bańka, 2004).

\subsection{Essence and types of career capital}

The main source of career capital is education (Turska, 2014). In the face of dynamic socio-economic changes and changing conditions of the individual's professional career, as well as the increasing ambitions to build a society of knowledge, it is becoming more noticeable that the organizations are more interested in having employees with higher education Therefore, in this study the considerations were narrowed to the career capital of university graduates, bearing in mind the fact that, this type of capital determines the entry of young people into the labor market and that it is also a factor that helps graduates in selfdevelopment and in finding the job after studies (Bańka, 2005).

Career capital should be also understood as a "accumulated competences that the unit obtains in the course of education, job, life experience, social and cultural experience" (Bańka, 2006). This group of competences are the result of both: participation in the education process as well as personal interests and predispositions. What is more, they are also the possibilities resulting from the socio-economic status of the individual and the undertaken professional activities (Bańka, 2005). 
Career capital term (also referred as start-up career capital) is heterogeneous, but by following E. Turska we should outline four main types of career capital: educational capital, experience capital, entrepreneurship capital and language capital (Turska, 2014) (fig. 1).

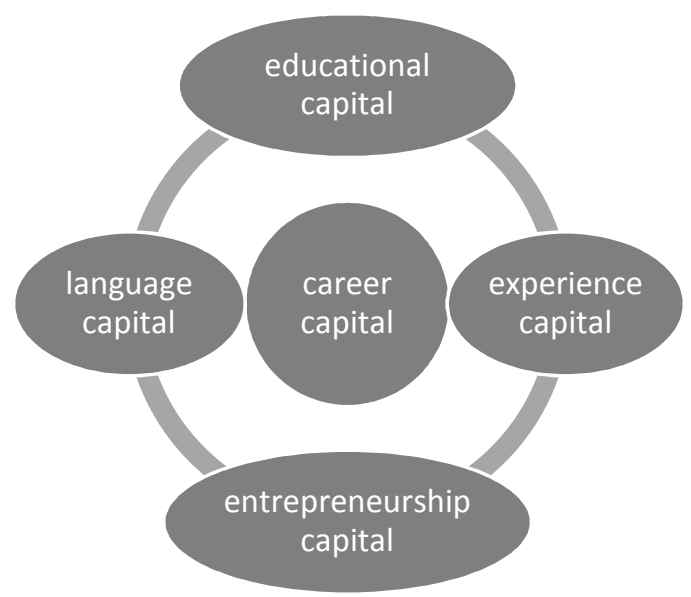

Fig. 1. Types of career capital

Source: Own elaboration based on (Turska, 2014).

Educational capital should be perceived as the difference between the resources of initial knowledge and the knowledge obtained after finishing the studies by the graduate (Dworak, 2012). The measure of another type of capital: professional experience capital, is the difference between the received human capital and the sum of the cost of living and received education (Dobija, 2002). Entrepreneurial capital, manifesting itself in proactive behavior that creates and change the reality (Bańka, 2006), is extremely important for professional starts and functioning in the modern labor market (Strykowska, 2012). Language capital is an ability of a graduate to use a foreign language (or few of them).

In the further part of this article, the authors are focusing on the first of the mentioned types of career capital - educational capital.

\subsection{Educational career capital creation}

So far, there is no proper tool that accurately evaluates and estimates human capital (as well as career capital) that can be represented by students or university graduates (Wiktorzak, 2009). However, the value of human capital can be represented by so-called Virtual Production Line (VPL), which compares the process of creating and extending the individual human capital to the so-called Classical Production Line (CPL) (Walukiewicz, 2011). What is more, Walukiewicz emphasizes that human capital is a component in the process of creating new patents and innovations. Virtual Production Line can be also showed as a extending career capital process on the ground of education (fig. 2).

Graduates of higher education institutions, after completing the didactic process, create a new value on the labor market, as a supply for new capital. According to the Central Statistics Office report (CSO, 2018) in the academic year 2017/2018 in Polish higher education schools (public and non-public) about 329,000 students have begun their studies and 
about 388,000 graduates have made their first steps on labor market ${ }^{3}$ (the largest percentage of them, $29 \%$ graduated from Universities) - chart 1.

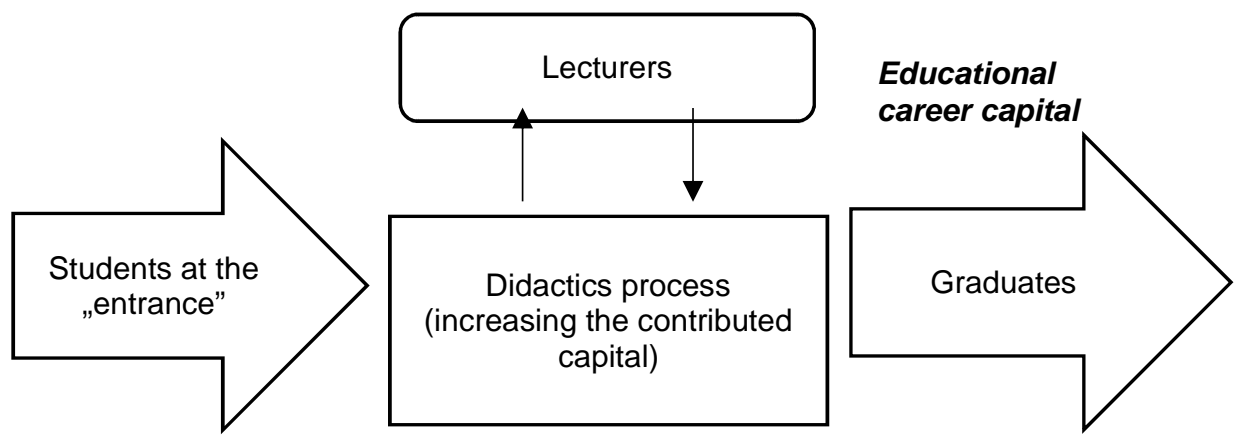

Fig. 2. The process of expanding educational career capital in accordance with the VPL

Source: Own elaboration based on (Wiktorzak, 2009; Walukiewicz, 2011).

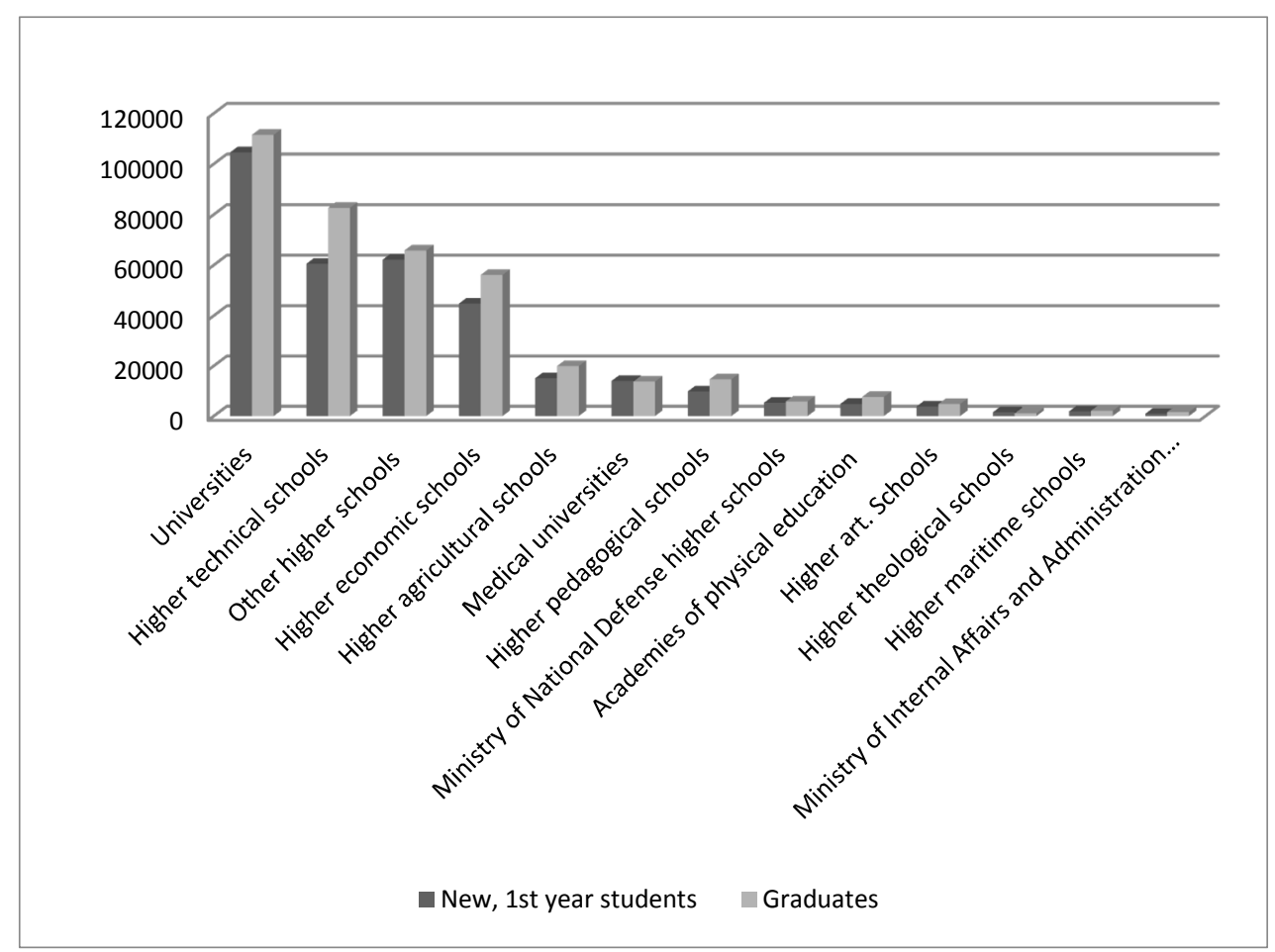

Chart 1. New, 1st year students and university graduates in the 2017/2018 academic year Source: Own elaboration based on statistic data from CSO.

\footnotetext{
${ }^{3}$ This number applies to both Polish citizens and foreigners studying at Polish universities.
} 
According to the analysis above in Chart 1, most Polish universities have higher number of graduates than the new students. This trend was also noticeable in the previous year. In addition, according to the Ministry of Science and Higher Education report: "Higher Education in Poland", in recent years, the total number of students in Poland has decreased. As a comparison, in the year 1990/1991 in Poland, there was only 390,000 students. This number has increased 5 times over next 15 years (up to 1.95 million in the year 2005/2006). Despite this fact, in subsequent years there were fewer and fewer students, and according to the Ministry's forecasts, the downward trend will continue until 2025, when there will be 1.25 million people in higher education.

It should be said, that for modern organization, employing people with higher education is a relatively good and cheap way to have a quick access too current knowledge. In the context above, the phenomenon of a smaller number of newly accepted students in relation to the number of university graduates as well as downward trend in the total number of students, can be a source of concern. Moreover, it is especially important for employers, taking into consideration the actual time of decreasing access of higher educated employees with proper educational capital.

One of the indicators, which may measure the size of accumulated educational capital is the number of studies performed simultaneously. One of the thesis that can be made is that the person who ends one field of study has a lower educational capital than a person who study in more than one field of study (Turska, 2014). At the end of the year 2017 (November 30th), the number of students studying in more than one direction was around 41600 people which represents only $3.2 \%$ of all students registered in the academic year 2017/2018 (CSO, 2018).

\section{PROFESSIONAL ACTIVITY MODEL AND EDUCATIONAL CAREER CAPITAL}

The modern socio-economic environment changes require constant redefining of the essence of professional choices. The well-known globalisation and current international economic integration in Europe also require different planning of the professional future, taking into account both the traditional individual aspects and the context of changes related to transformations in the labor market. The professional activity model assumes the sequence of events (unchanged in time) that no longer fits the reality that surrounds us. This events are:

(1) making a decision about choosing a profession,

(2) process of acquiring knowledge (going through the various stages of education),

(3) enter the labor market,

(4) working in acquired profession until retirement (Barwińska-Małajowicz, 2015).

In addition, it is worth noting that the first three stages of the professional activity model do not have a constant, specific form, because whole process depends on the individual decisions of the person who already has a part of the accumulated capital, starting from the moment of entering the University - chart 2. What is more, the decision about choosing the profession can be already changed at stage 2, especially in situation where $48.7 \%$ of graduates (officially) do not find work in their profession despite the fact of having knowledge and professional skills in form of educational capital.

At this point we can ask one question: What are the conditions of making such decisions? Looking for the answer, it is worth to find how the modern world works. In the 
description of the modern world, Bauman uses the adjective "flowing", which means that everything in our reality is changeable, temporary, momentary, it changes all the time, at a pace and direction difficult to predict (Bauman, 2006). Man goes with the flow of the ocean of changes, ,drifts" in search of new marinas" (Bauman, 1994) and what he would (...) never do, he will never be sure that he has done what it needed to be done" (Bauman, 1994). According to W. Sztumski

we live in a "non-stop" society, in a world in which we living by "the principle of acceleration and racing with" escaping time (Sztumski, 20069). We are moving faster and faster and we are dealing with growing turbulent movements and that is way our modern world is also called "turbo-world". It is characterized by increasing fast-changing, uncertainty and unpredictability and in such an environment it is extremely difficult to live (Sztumski, 2006, s. 49).

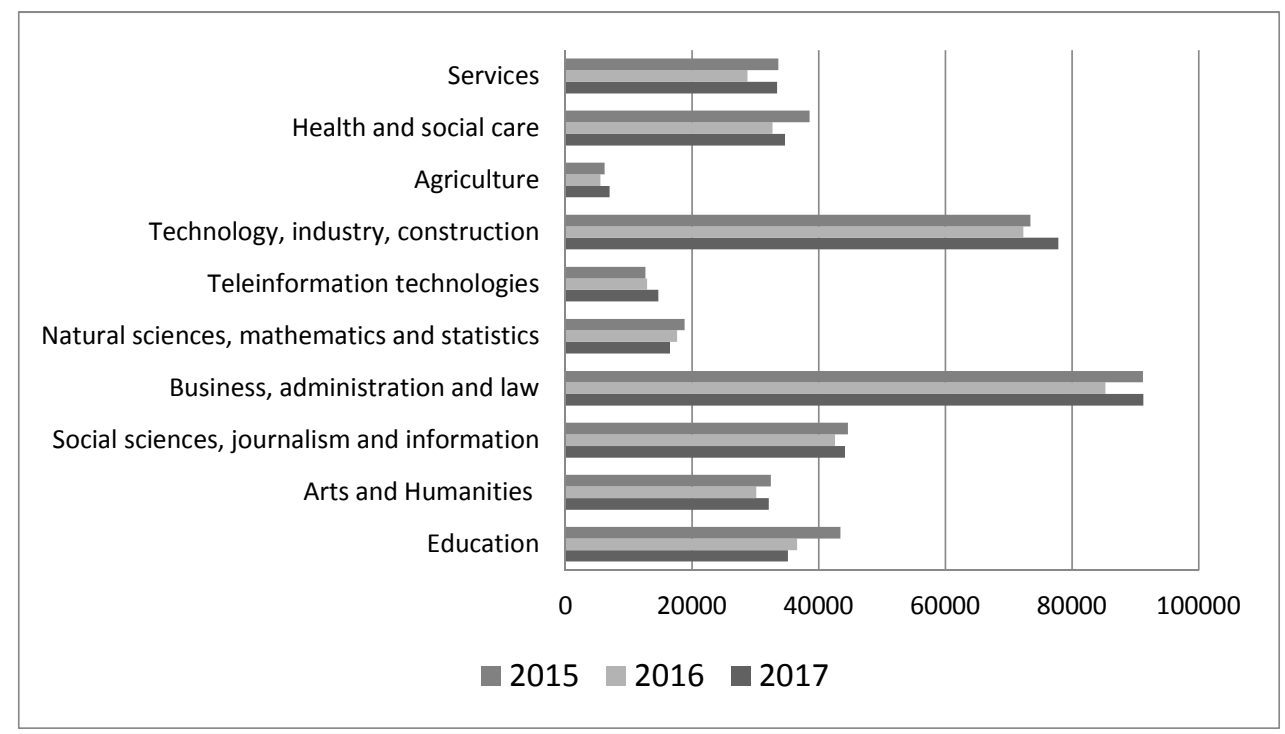

Chart 2. Higher education graduates in Poland by groups of field of studies (academic year 2017/2018)

Source: Own elaboration based on statistic data from CSO.

The way to escaper from this acceleration trap lies in

finding the right measure of time and in slowdown the pace of life (...). That is why, people are trying to rebuild the old convention of slowness and bring to life also old Roman maxim: Festina lente! (,Slow and steady wins the race”.) (Sztumski, 2006).

Sztumski also claims that: "before we get used to living under current conditions and adapt to them, they will already change" (Sztumski, 2006), that is why in the face of often 
unpredictable changes and labor market demands, modern employee should have three essential features: flexibility, openness and mobility.

In the face of the modern world volatility, it is not easy for young people to make accurate career choices that allow them to combine their own abilities and passions with the rapidly changing reality of the labor market. Among the criteria that young people should undoubtedly take into consideration when choosing the path to build their own educational career capital, they should include also the expectations and preferences of employers. Potential employers prefer to employ the graduates often from technical faculties (which are innovative and developmental) such as e.g. IT, automated technology, robotics, telecommunications, electrotechnics, faculties related to the construction and automation of machines and also from technological processes or microprocessing systems. If the profile of educational career capital, even built with extreme care, reliability and attention to high quality, is not adapted to the profile of requirements reported by the labor market, it will not be appreciated by employers, and it will be difficult for graduates to find a satisfactory job in their profession. The analysis of data compiled in Chart 2, which shows that in the last few years, relatively many higher education graduates have graduated the faculties of technology, industry and construction, raises some hope that the profile of educational career capital built by many young people is shaped consciously and in line with labor market expectations. On the other hand, a small percentage of graduates of ICT fields shows that there are still a lot of information and awareness deficits in this area.

Finally, it is worth adding that the natural feature of any dynamically developing economy is the temporary structural mismatch between supply and demand on the labor market. Requirements and sought competences change faster than the higher education program, which generates bigger problems for future graduates in making decisions about starting the right career path (Balcerowicz-Szkutnik, Skórska, Wąsowicz, 2017). What is more, this situation is intensified by the increased economic migration of Polish citizens, who, as reasons for emigration, points, apart from higher salaries, a better prospect for personal development (Work Service, 2018).

\section{SUMMARY}

In modern world, professional career has more personal (subjective) character.

A career is always someone's. It is a human life's stage that relates to experience, at least a mental one. It is not just a profession, such as e.g. teacher or lawyer, nor a sum of only individuals objective achievements. Professions becomes more and more just a context in which the career took place (Bańka, 2004).

In this regard, the process of education and learning is important, as a result of which the unit broadens and enriches its competences (accumulates educational career capital). It is worth bearing in mind that accumulated educational capital is part of the mechanism by which the modern labor market functions. That is why, on the one hand, transparency and adequate building of career capital among graduates of higher education schools is so important, because they are also a new generation and source of labor supply in the modern labor market. On the other hand, if the profile of educational career capital is not adapted to the profile of requirements reported by the labor market, it will not find a demand from employers, thus it will be difficult for graduates to find a satisfactory job in their profession. Due to the volumetric framework of this study, the article drew out only selected issues in the field of undertaken problematic aspects. It should be said, that the authors research about 
the educational career capital of higher education students and graduates (which includes the motives of choosing individual fields of study, ways and possibilities for students to acquire knowledge, competences and skills that create educational capital and its impact on the career path of graduates) conducted at regional level, are now in the final phase and its results will be presented in subsequent studies.

\section{REFERENCES}

Balcerowicz-Szkutnik, M., Skórska, A., Wąsowicz, J. (2017). Perspektywy zatrudnienia absolwentów na polskim rynku pracy. Studia Ekonomiczne. „Zeszyty Naukowe”, Uniwersytet Ekonomiczny w Katowicach nr 316.

Bańka, A. (2005). Kapitat kariery - uwarunkowania, rozwój i adaptacja do zmian organizacyjnych oraz strukturalnych rynku pracy [w:] Ratajczak, Z., Bańka, A., Turska E., Psychologia pracy i organizacji w okresie zmian systemowych. Katowice: Wydawnictwo Naukowe UŚ.

Bańka, A. (2006). Psychologiczne doradztwo karier. Poznań: Stowarzyszenie Psychologia i Architektura.

(2013). Rozwój i zastosowanie teorii psychologicznych w wspótczesnym doradztwie karier w kontekście integracji transkulturowej. „Chowanna” $\mathrm{nr} 23, \mathrm{t} .2$.

Barwińska-Małajowicz, A. (2013). Start zawodowy absolwentów szkót wyższych w Polsce $i$ Niemczech. Analiza porównawcza $w$ ujęciu ogólnokrajowym i regionalnym. Warszawa: CeDeWu.

(2015). Tranzycyjny kapitat kariery absolwentów szkót wyższych w Polsce - wybrane aspekty teoretyczne i empiryczne. „Nierówności Spoteczne a Wzrost Gospodarczy”, $\mathrm{nr} 42$.

Bauman, Z. (1994). Dwa szkice o moralności ponowoczesnej. Warszawa: Instytut Kultury.

- (2006). Ptynna nowoczesność. Kraków: Wydawnictwo Literackie.

Cybal-Michalska, A. (2013). Młodzież akademicka a kariera zawodowa. Kraków: Oficyna Wydawnicza „Impuls”.

Dobija, M. (2002). Struktura i koszt kapitatu ludzkiego. „Zeszyty Naukowe” nr 562, Kraków.

Dobija, M., Dobija, D. (2003). O naturze kapitału. „Zeszyty Teoretyczne Rachunkowości”, Łódź, t. 17.

Dworak, J. (2012). Kapitat edukacyjny jako determinanta atrakcyjności szkoły wyższej. Zarzqdzanie marka w szkołach wyższych. „Wybrane Problemy” nr 44, Poznań.

Gościński, J.W. (1989). Cykl życia organizacji. Warszawa: PWE.

Grodzicki, J. (2003). Rola kapitału ludzkiego w rozwoju gospodarki globalnej. Gdańsk: Wydawnictwo Uniwersytetu Gdańskiego.

Krause, E. (2006). Modele (przebiegu) kariery zawodowej człowieka. „Problemy Profesjologii” nr 1.

Marchewka, K. (2000). Główne nurty w teorii kapitatu. „Ruch Prawniczy, Ekonomiczny i Socjologiczny", R. LXII, z. 3.

Pacioli, L. (2007). Tractatus XI de computis et scripturis: summa de arithmetica, geometria, proportioni et proportionalità, Stowarzyszenie Księgowych w Polsce, Warszawa: Centralny Ośrodek Szkolenia Zawodowego.

Penc, J.(1997). Leksykon biznesu. Warszawa: Agencja Wydawnicza Placet.

Raport MNISW, W 10 lat liczba studentów w Polsce spadnie o 400 tys. [Access: 10.10.2019]. Access on the Internet: http://naukawpolsce.pap.pl/ aktualnosci/news\%2C396397\%2Craportmnisw-w-10-lat-liczba-studentow-w-polsce-spadnie-o-400-tys.html

Report GUS. Szkoty wyższe i ich finanse w 2017 r. 2018. 
Report Work Service. Migracje zarobkowe Polaków IX - listopad 2018.

Strykowska, M. (2012). Zarządzanie kariera zawodowa jako forma przedsiębiorczości [w:] Ratajczak, Z. red., Przedsiębiorczość. Źródła i uwarunkowania psychologiczne. Warszawa: Wydawnictwo Difin.

Super, D. (1976). Career education and meaning of work. Monographs on career education, DC: The Office of Career Education, Washington: U.S. Office of Education.

Sztumski, W. (2006). Turboświat i zasada odśpieszania. „Problemy Ekorozwoju - Studia Filozoficzno-Sozologiczne” t. 1, nr 1.

Taghizadegan, R., Kapital und Wohlstand, Institut für Wertewirtschaft, Wien. Access on the Internet: http://wertewirtschaft.org/analysen/Kapital.pdf.

Turska, E. (2014). Kapitat kariery ludzi młodych - uwarunkowania i konsekwencje, Katowice: wyd. Uniwersytetu Śląskiego.

Walukiewicz, S. (2011). Measuring Social Capital and Proximity, ERSA conference papers ersa10p309, European Regional Science Association.

Wiktorzak, A.A. (2009). Wirtualna Taśma Produkcyjna w badaniach edukacyjnych, Badania międzynarodowe $i$ wzory zagraniczne $w$ diagnostyce edukacyjnej. XV Krajowa Konferencja Diagnostyki Edukacyjnej, Kielce.

— (2011). Edukacja a wartość kapitału ludzkiego. Ewaluacja w edukacji: koncepcje, metody, perspektywy. XVII Krajowa Konferencja Diagnostyki Edukacyjnej, Kraków.

DOI: $10.7862 /$ rz.2019.hss.22

The text was submitted to the editorial office: April 2019.

The text was accepted for publication: September 2019. 